\title{
Genre-Based Approach to the Teaching of Pronunciation
}

\section{Uma Abordagem via Gêneros Textuais para o Ensino de Pronúncia}

\author{
Marden Oliveira Silva ${ }^{1}$ \\ Danielle Carolina da Silva Guerra²
}

\begin{abstract}
Resumo: Em contextos de ensino e aprendizagem de inglês como segunda língua, professores não têm dado atenção suficiente ao ensino de pronúncia. Trabalhar aspectos segmentais e suprassegmentais por meio de uma abordagem baseada em gêneros textuais pode ser uma oportunidade de integrar aspectos de pronúncia a uma prática de aprendizagem mais significativa. 0 objetivo desta pesquisa foi realizar um levantamento de aspectos relacionados à pronúncia do inglês considerados mais difíceis de aprender por estudantes brasileiros. Isso possibilitou a discussão de estratégias capazes de facilitar o desenvolvimento das habilidades orais nas aulas de inglês, integrando o ensino dos aspectos fonético-fonológicos na abordagem baseada em gêneros textuais. Noç̃es de inteligibilidade, fluência e acuidade foram propostas por alguns autores como uma sequência didática ideal. Alunos de nível básico deveriam ser expostos a atividades focadas na noção de inteligibilidade, assim como alunos intermediários à noção de fluência e os mais avançados, às práticas de acuidade. Os dados foram coletados durante três aulas de inglês do ensino médio no Centro Federal de Educação Tecnológica de Minas Gerais (CEFET-MG), por meio de questionários e atividades didáticas, as quais foram gravadas e transcritas para análise. 0 gênero debate foi escolhido para facilitar a expressão oral dos participantes de forma mais livre, ao responder a perguntas e opinar sobre um tema previamente selecionado. Muitos dos aspectos de inteligibilidade analisados tiveram que ser observados mais de uma vez. As falas dos alunos intermediários foram mais fáceis de entender, porém eles consideraram mais difícil pronunciar as palavras fluentemente. Por fim, os alunos mais avançados pareciam expressar suas ideias de forma mais fluente, mas questões sutis relacionadas à acuidade foram perceptíveis, confirmando assim a hipótese proposta. Verificou-se também que a abordagem de gêneros para promoção da comunicação oral nas aulas de inglês pode ser relevante, considerando sua função sociocomunicativa.
\end{abstract}

Palavras-chave: Gêneros textuais. Habilidades Orais. Pronúncia.

Abstract: Pronunciation teaching hasn't been paid enough attention by teachers regarding ESL contexts. In particular, segmental and suprasegmental features through genre-based approach may be an opportunity on how to integrate pronunciation into a more meaningful learning practice. Therefore, the aim of this project was to carry out a survey on some aspects related to English pronunciation that Brazilian students consider more difficult to learn, thus enabling the discussion of strategies that can facilitate the development of oral skills in English classes by integrating the teaching of phoneticphonological aspects into the genre-based approach. Notions of intelligibility, fluency and accuracy were proposed by some authors as an ideal didactic sequence. Basic learners should be exposed to activities focused on the notion of intelligibility as well as intermediate students to the notion of fluency, and finally more advanced ones to accuracy practices. Data were collected during three high school English classes at Federal Center for Technological Education of Minas Gerais (CEFET$M G$ ), in Brazil, through questionnaires and didactic activities, which were recorded and transcribed for further analysis. The genre 'debate' was chosen to facilitate the participants' oral expression in a more flexible way, making them answer questions and give their opinion about a previously selected topic. Students demonstrated more difficulty with some aspects than others. Many of the intelligibility aspects analyzed had to be listened to more than once for a better understanding. Intermediate

\footnotetext{
1 Mestre em Estudos de Linguagens. Centro Federal de Educação Tecnológica de Minas Gerais - Campus I. Orcid: https://orcid.org/0000-0002-3644-4282 E-mail: marden@cefetmg.br

${ }_{2}^{2}$ Mestre em Estudos Linguísticos. Centro Federal de Educação Tecnológica de Minas Gerais - Campus I. Orcid: https://orcid.org/0000-0003-1134-4493 E-mail: danielle@cefetmg.br
}

LínguaTec, Instituto Federal de Educação, Ciência e Tecnologia do Rio Grande do Sul, Bento Gonçalves 
students' speeches were considerably easier to understand, but they found it more difficult to pronounce the words fluently. Lastly, more advanced learners seemed to express their ideas more fluently, but still subtle issues related to accuracy were perceptible, thereby confirming the proposed hypothesis. It was also seen that using genre-based approach to promote oral communication in English classes might be relevant, considering the socio-communicative function inherent to the approach.

Keywords: genre-based approach. Oral skills. Pronunciation.

\section{Introduction}

From a study carried out in the master's thesis of the supervisor of this project (SILVA, 2012), it was possible to observe that, although the different language skills were addressed in the classroom, the study of pronunciation in particular did not get the same attention (BAUER; ALVES, 2011 and PENNINGTON, 1996). In general, it can be observed that the phonetic-phonological aspects do not play their proper role in teaching, since in most of the available teaching materials (basically textbooks), pronunciation is not addressed in an integrated way to the other linguistic abilities, which is believed to impair the proficient use of the second language.

It's important to explain two concepts that are relevant to this research: second language (SL) and foreign language (FL). Mitchell \& Miles (1998) define SL as a later language acquisition, which happens after the first language. Second languages are any other languages but the learner's native one. The authors consider that the term 'second languages' encompasses the term 'foreign languages'. Similarly, Ellis (1997) claims that it doesn't matter whether the language was learned in the country where it is spoken or in classroom; the term SL would be more appropriate in either case. In this paper, the expressions 'second language' and 'foreign language' will be used as synonyms.

In order to integrate second language (SL) pronunciation teaching with the other language skills (written comprehension, written production, oral comprehension and oral production), it is important to stick to a contextualized and meaningful pedagogical practice, according to the Foreign Language Curriculum in High School (Proposta Curricular para Língua Estrangeira no Ensino Médio da Rede Estadual de Ensino de Minas Gerais, MINAS GERAIS, 2005), so that the students can have real experiences of interaction in the classroom as well. In order for such an objective to be achieved, pronunciation teaching based on the presuppositions of the theory of textual genres was chosen, a theory defended by Bakhtin (2003), who understands language as a social, historical, and ideological phenomenon, in which the utterance is understood as a unit of verbal communication, provided that there is alternation among the interlocutors with a specific purpose. It is from Bakhtin's perspective that Dolz and Schneuwly (2004) use genres as instruments for teaching. This same proposal is suggested by the official texts when encouraging the use of diverse genres in the teaching of foreign language for High 
School (Orientações Curriculares para o Ensino Médio - Linguagens, Códigos e suas Tecnologias, BRASIL, 2005). The proposal of this research is also in line with the work currently carried out at the Department of Language and Technology at CEFET-MG, Campus I, about the implementation of a new Political Pedagogical Project via textual genre approach for teaching English as a Second Language (ESL).

\section{Motivation and Relevance}

In addition to the development of the written modality, one of the main goals for teaching EFL in regular secondary education is to improve students' perceptual and oral skills so that they can deal with practical situations to use the target language (MINAS GERAIS, 2005). Since these skills also contribute to the development of the communicative competence, it is understood that the teaching of pronunciation must be taken into account from the initial years of contact of the student with the English language, which in the case of CEFET-MG begins in the 1st high school classes. Focusing specifically on the teaching and learning of aspects related to pronunciation, we seek to describe some important underlying concepts, as well as to prepare a proposal that fits that specific institution.

Literature on second language acquisition suggests that, with the strengthening of the Communicative Approach, between the 1970s and 1980s, the formal correction of structures was substituted for that new method of teaching and, under its influence, any material that addressed the segmental component, strongly practiced in the past, would be replaced (NETO; VASCONCELLOS, 2003). Richards and Rodgers (2001) highlight that the Communicative Approach is related to the notion that the learning of a language happens through its use for communication, so the goal of the classroom activities should be "authentic and meaningful communication" (p. 172), integrating multiple linguistic abilities in order to reach fluency.

It is considered, however, in agreement with other authors, that once the idea that the different approaches must be complementary and non-substitutive stands out, antagonistic positions used in the field of linguistics can be treated in relative terms (CELCE-MURCIA; BRITON; GOODWIN, 2010), which, in turn, will enable the development of more pedagogical practices. This way, the issue of teaching oral skills - focusing on aspects of pronunciation - integrated to the genres approach can be positive in relation to their development.

In order to achieve the objectives here, the work of both segmental (related to, or constituting an isolable speech sound) and suprasegmental (pertaining to a feature of speech that extends over more 
than a single speech sound) aspects of the target language seems to be relevant, as also suggests the Curricular Proposal for Foreign Language in Secondary Education (MINAS GERAIS, 2005). This way, students become able to construct meaning based on such FL sound marks. Still according to the proposal, and in line with the ideas of Jenkins (2000) and Crystal (2003), these aspects should focus on the acquisition of an intelligible pronunciation, in contrast to the focus given to the pronunciation of the native speaker. However, it is important that the transference of sound aspects of the mother tongue (which differ from the FL) does not impair the intelligibility of the communication, as well as sounds of English considered difficult for Brazilian speakers are taken into account by the teacher in the teaching and learning process (COLLINS; MEES, 2008 and LIMA-JÚNIOR, 2010).

\section{Objectives}

The main objective of this research study is to analyze the students' perceptions regarding the development of oral skills from a genre-based approach. The specific objectives are:

i) to carry out a survey of aspects related to the pronunciation of the English language that Brazilian speakers consider most difficult in EFL context; and

ii) to discuss the role of textual genres in the development of English pronunciation.

\section{Theoretical Framework}

During the first months of this project, some texts from several theorists of the area were read and analyzed to provide an interpretation of the objectives proposed. Those texts focused on understanding the major problems currently found in the teaching of SL pronunciation worldwide, analyzing students' greatest difficulties. The texts also analyzed how pronunciation was taught in schools over the years, with research that proved (or not) the effectiveness of a number of methods and theories. These files were also an efficient source of references to be used in the practical part of this project, demonstrating effective ways of collecting and analyzing information.

Bearing in mind the aim of this project, which is to integrate the teaching of phonetic-phonological aspects into a practice focused on the textual genres approach for the development of oral skills, we present some considerations about works related to pronunciation teaching and the teaching of L2 through this approach that have already been conducted. However, it is important to point out that there is still little (or even no) research addressing the teaching of $L 2$ pronunciation integrated with the approach mentioned. The approach through textual genres was basically rooted in the presuppositions of the sociointeractionist bias, which, in turn, has its basis in Vygotsky's theory. The main idea that this part defends 
refers to the presence of a third mediating element between humans and the world in the process of language acquisition, be it another individual or the learner itself (BAMBIRRA, 2007).

The socio-interactionist theory gave support to the fact that Vygotsky's thought about human cognition in the process of learning was transferred to a new theoretical, sociocultural line of thought (LANTOLF; THORNE; POEHNER, 2015), which supports us in the development of this project.

In general, sociocultural theory has as one of its roots the understanding that the human mind is mediated by artifacts, whether symbolic or material, that is, the individual does not act directly in the physical world in which they live without the use of tools that play the role of mediators of the construction of mental activities. All this construction takes place under specific historical and cultural conditions. Vygotsky claims that

Every function in the child's cultural development appears twice: first, on the social level, and later, on the individual level; first, between people (interpsychological) and then inside the child (intrapsychological). This applies equally to voluntary attention, to logical memory, and to the formation of concepts. All the higher functions originate as actual relationships between individuals (Vygotsky, 1978, p.57).

Swain, Kinnear, and Steinman (2011) define sociocultural theory as the means by which human beings think through the creation and use of mediation tools. Another premise that underlies this line of thought concerns the importance of interaction in the learning process, since it is through this that the learner can co-construct their knowledge with the participation of more linguistically competent individuals. In the classroom context, for example, there is the possibility of the participation of students and teachers in collaborative tasks with specific purposes. In the accomplishment of these tasks, by the interaction, zones of proximal development (ZPD) are constructed, which foster the learning (ELLIS, 2005). The difference between what the learner can perform without the aid of another one and what he can achieve with the cooperation of a more competent pair is understood as ZPD. Scaffolding actions are fundamental in the social mediation task that takes place in the ZPD. Vygotsky defines scaffolding instruction as the "role of teachers and others in supporting the learners development and providing support structures to get to that next stage or level" (Raymond, 2000). Under the sociocultural aspect, it is remarkable that social practices have been mediated by new technologies, in an increasingly multimodal world. Therefore, it is important to think of the integration of students in these contexts, since the lessons developed with these instruments seem to have great potential to become more interesting and meaningful. Chapelle (2003) states that the contact of students with authentic content through the Internet is a source of input full of new information that, when understandable, it can aid in the acquisition process of the target language. Still in the same rationale about the use of new technologies, Brown (1994) states that they can motivate students in discovering new meanings through the vocabulary employed in the classroom. 
Still regarding motivation, Ushioda (2008) claims that students are motivated when there is a sense of continuity between what is done and learned in class and who they are and the interests they have inside and outside the classroom, now and in the future.

Based on the sociointeractional language view, the teaching objects proposed for the development of oral skills are the different textual genres found in the society nowadays. The approach to teaching through genres allows students to be prepared for the social practices which they have to interact with daily. From the theorization that genres are relatively stable types of utterances and the medium through which we communicate (BAKHTIN, 2003) it is important to know how to take advantage of this relative stability so that students can recognize the various texts and interpret them according to the textual characteristics during the learning process.

In addition, the different genres can be presented to students through these new teaching tools, making classes closer to personal interests and, consequently, creating more motivating strategies for the development of language skills and encouraging new ways of re-signification of content.

\subsection{A genre-based approach in ESL}

Some studies have demonstrated the effectiveness of working with different genres in the context of FL classrooms (BAMBIRRA, 2004; DIAS, 2011; MEURER; MOTTA-ROTH, 2002; PAIVA, 2005; PINTO, 2002). Bambirra's work (BAMBIRRA 2004; 2007), for example, sought to investigate the teaching of writing skills in English as a FL among elementary school students. The results indicated that there was a significant improvement in the students' interpretation of texts and their production, as well as the creation of more effective texts for the achievement of the various social functions to which they were exposed. In the same way, Dias (2011) presents a general analysis of the approach through textual genres in second language textbooks and suggests the use of such an approach for teaching and learning language practices. Pinto (2002) similarly suggests how textual genres can be inserted in school contexts and also points out how they can contribute to the reception and production of the information that is meaningful to learners. Paiva (2006) refers to the concept of genres and their association with language teaching, and pointed out its importance, without naming it explicitly. Finally, Meurer and Motta-Roth (2002) emphasize how individuals produce, reproduce and change their social realities from texts, and show the impact of those actions in classroom. 


\subsection{Pennington's proposal}

According to Pennington's proposal, the aim of pronunciation teaching should be based, in order of priority, on the three notions that follow: intelligibility, fluency, and accuracy. The term intelligibility has been widely discussed by scholars such as Jenkins (2000) who elaborated, in her seminal book English as a Lingua Franca, a list of phonetic-phonological aspects considered more relevant to teaching and which, according to the author, should be prioritized for communication to happen among non-native speakers of SL since these are currently the majority (CRYSTAL, 2003). Making communication intelligible means that the learner can manage to be understood, which is not a simple task in the initial years of learning. Consequently, this notion should be emphasized from the first contact of the students with the SL, since it can contribute to the formation of their linguistic competence. In addition, the notion of fluency, that is, the ability that the learner begins to demonstrate in relation to the articulation of the sounds of the SL must be subsequent to that of the intelligibility in the practice of teaching, proper place for the development of this ability. Finally, the notion of accuracy should be the last stage to be focused on the didactic process, since on this stage the focus is on the phonetic accuracy of the sounds previously worked out, which consequently requires a more advanced level of proficiency from the student.

Therefore, considering the need to present the different notions of pronunciation to the student in order to meet the proposal defended by Pennington, we chose to integrate such notions to the use of textual genres that surround the different social spheres in which students are inserted.

\section{Methodology}

Since the focus of this research is working through textual genres, which might be tied to the segmental and suprasegmental aspects of SL, Pennington's proposal will be directed to each school grade, specifically. For data collection, we have chosen the genre 'debate' to facilitate the oral expression of the participants freely, and also the recording of the speeches for later analysis of the aspects suggested by the author. First-grade students focused on the notion of intelligibility, since, theoretically, they can be considered less proficient in the language. Second-grade students were specifically analyzed within the notion of fluency, understanding that they are, to a certain extent, more competent than the students in the previous grade and can already be understood in certain communicational situations. On the other hand, third-grade students shifted our attention to the aspects of accuracy of the sounds of the $\mathrm{SL}$, since they are expected to be linguistically more competent than the members of the other previous grades. 
A genre-based approach, which is used at CEFET-MG, Campus I, focuses on the development of tasks, in group or individually, aiming at fostering students' linguistic competences. In this context, the student is the main agent of their own learning process, and the teacher works as a mediator, giving feedback and leading the group. The integration of communicative abilities is an important feature of the production of written and oral genres, through the use of a wide range of digital tools. Besides, the English teachers at this institution decided on a genre-based curriculum taking into account its potential to connect students' lives to what is done in class. The formal written and oral tests have been substituted by the production of textual genres, which means that students are not supposed to be separated by levels. Although the groups are quite mixed in terms of proficiency, they present a relatively stable pattern of pronunciation errors, according to their grade. The Foreign Language Curriculum in High School (Proposta Curricular para Língua Estrangeira no Ensino Médio da Rede Estadual de Ensino de Minas Gerais, MINAS GERAIS, 2005) recommends assessment should be done throughout the classes, by means of feedback, instead of being a final goal with point value.

\subsection{Questionnaire}

The questionnaire sought to clarify possible issues about the general difficulties students have in learning English pronunciation. The goals of the questions were:

- Question 1: It aimed at clarifying students' view of their own abilities regarding English pronunciation. This way, it was possible to recognize the level of each group.

- Question 2: It sought to find out difficulties students have while speaking English. The alternatives rely on sounds of the language that are commonly mispronounced by students who are not used to the phonetics of the English language yet.

- Question 3: When analyzing the answers to this question, it was possible to see the relevance of the teaching of pronunciation in schools. Since it is a technician school, the students are mixed and probably attended different educational institutions in the past, which enriches the research.

- Question 4: It aimed to verify the students' knowledge regarding the phonetic alphabet. This aspect of the English language is often not part of the high school curriculum, although it might be important.

- Question 5: It aimed to investigate students' knowledge of the technical terms (intelligibility, fluency and accuracy) that are the focus of this project.

- Question 6: With this question we sought to know the level of confidence of the students when speaking English in a real interactional situation. 
- Question 7: The last question was about the students' opinion about the need to teach pronunciation in English classes, and they were asked to give a reason.

\subsection{Questionnaire Application}

The questions were answered during three 50-minute classes for three different grades. First, second and third grade students should individually answer the questions proposed. Each class had approximately 20 students who did not demonstrate difficulties to perform the activity. Questions related to technical terms and questions interpretation were also observed.

\subsection{The activity on the genre 'debate'}

From the analysis of the questions, a specific genre was selected by the advisors who conducted this project. Considering that the discussion is a way to provide a greater oral interaction between individuals, we decided that the genre debate would be suitable for this research.

During a 50-minute class, one for each grade, an activity that would require the student's oral interaction with their classmates was performed. It was called "Hot Air Balloon" (see Appendix), and consisted of a hypothetical situation in which everyone in the classroom would be in a hot air balloon about to fall. In order for everyone to be saved, two individuals would have to be thrown out of the balloon, for it was overweight. The students would have to present a short speech that would justify why they deserved to stay alive, based on their hypothetical occupation (which was randomly selected previously) and the result would be announced by the teacher in the end. As a way of collecting material for analysis, each of the students who spoke had their speech recorded. From the recordings we were able to identify which / if the aspects proposed by Pennington were or were not confirmed. 


\section{IN or OUT?}

You have gone in a hot air balloon trip. Unfortunately there has been a storm and you have been blown over a mysterious and inhabited island towards a volcano. The balloon is too heavy, so two people will have to be sacrificed to save the rest. Each person in the balloon has a different occupation, so you have to persuade the others not to choose you to be thrown out of the balloon, based on your abilities. You'll have two turns: one to convince your colleagues you are important for the group's survival on the island and another one to choose someone to be sacrificed and

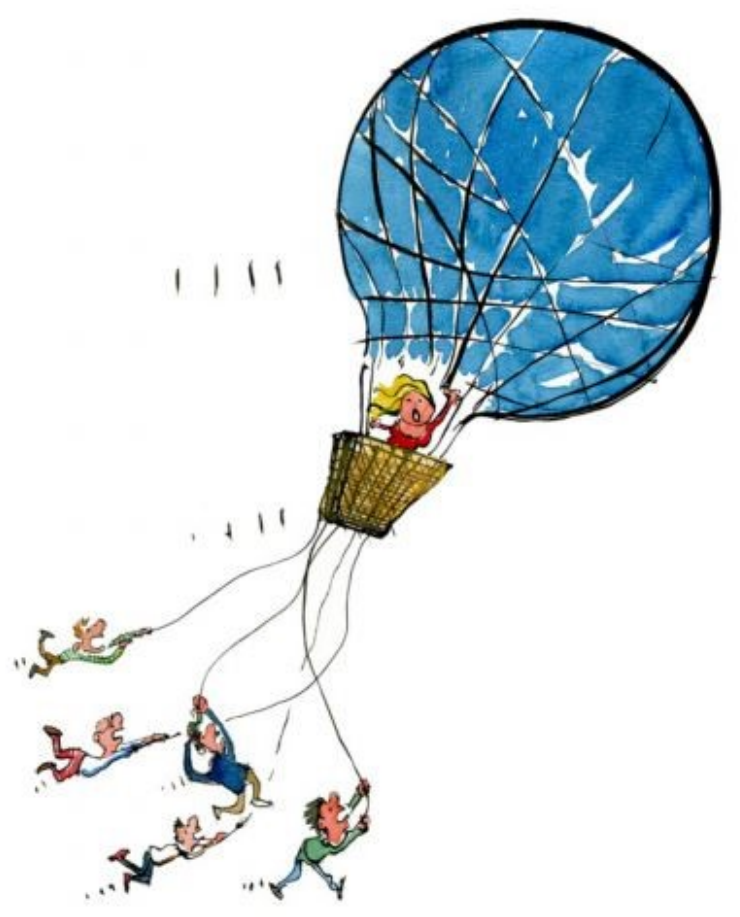
justify it.

Figure 1. Hot Air Ballon activity

Source: Google Images

\section{Questionnaire Analysis}

First, all the surveys were collected so they could be scanned using Google Forms production tool. This way, the analysis of the students' answers was made considerably easier. The questionnaires were separated by students' grades (1st, 2nd and 3rd), for a better interpretation of the data according to the theory proposed in the theoretical framework. Most first-graders considered their own pronunciation of English bad, having a greater difficulty with the phonetics of words like "girl" and "pearl" that have the "rl" consonants in a row. They claimed to have had very little approach to pronunciation teaching during the time they attended English classes. Thus, they had never seen or only heard of phonetics and its function in the language. Moreover, most of the learners also did not know the terms fluency, accuracy and intelligibility nor the way those were applied in the pronunciation of the second language. The lack of confidence in speaking English to others was also extremely common, mostly because of the fear of mispronouncing words and lack of vocabulary. Regardless of all this, 95\% of them considered the teaching of pronunciation essential, mainly because of its importance during a real-life dialogue. 
Second-graders, on average, claimed to have a regular pronunciation level, with greater difficulty in words with 'rl' consonants, as well as the first-grade students. Unlike the previous group, they said they had experienced pronunciation teaching just like vocabulary and grammar. In addition, a large share of students demonstrated some knowledge about phonetic symbols, although most of them have only heard of it. Like the first-graders, many of them did not know the difference between intelligibility, accuracy and fluency, but they considered the lack of vocabulary - and not the fear of misunderstanding the words - the main reason not to speak English to someone else. In general, $90 \%$ of the participants considered the teaching of pronunciation essential.

Finally, the third-graders' answers were more varied. Although the majority considered their own pronunciation bad, the answers were well divided among the other options. Learners had the same difficulty with words with 'rl' consonants and with words beginning with 'th'. An equal number of people also claimed to have had almost no pronunciation lessons during classes, and to have studied vocabulary and grammar equally. They were also divided between the shallow knowledge of phonetic symbols and the "I have already heard about it". Like the other grades, however, most students claimed not to know how to differentiate intelligibility from accuracy and fluency. They would not speak English to someone else due to the fear of misunderstanding and considered pronunciation an essential topic to be taught in English classes.

\subsection{Debate activities}

The students' speeches were analyzed taking into account their pronunciation, so that it was possible to successfully relate the theories with the practice. Some aspects of the English pronunciation have been more challenging to first-grade students than to the other ones. Many of the speeches had to be listened to more than once for better comprehension, thus confirming that intelligibility would be the aspect that should be addressed in first-grade classes. In the second-grade group, the speeches were considerably easier to understand, but students found it more difficult to pronounce the words fluently, often interrupting their speech to think of what they were going to say next and how they would say it, stuttering at many moments. Therefore, fluency was regarded as the aspect that should be approached in second grade classes. Finally, most third-graders presented their ideas almost fluently, but still subtle unexpected forms were perceptible in speech, which would validate the focus on the accuracy aspect in third-grade classes. 


\section{Conclusion}

Through the triangulation of the data collected in the questionnaire and students' speeches recordings, we conclude that the ideas proposed by Pennington (1996) may be applied to the context analyzed in this project. The first-graders have demonstrated unexpected forms in their oral expression in general, often being misunderstood by their colleagues and teachers, although specifying the difficulty with the sounds of the "rl" consonants. The second-graders' speeches were understandable. However, some issues in the fluency of sentences and in the pronunciation of words were evident. It was possible to notice some difficulty in the formulation and pronunciation of more complex sentences. Finally, the recordings of the third-grade students have shown a greater mastery of the aspects of pronunciation, in a big picture. On the other hand, there have been simple accuracy issues almost imperceptible, since they are students of a more advanced group. Regardless of what students answered in question two, the errors were not limited to one simple sound. More complicated words, which have unfamiliar pronunciation to Portuguese speakers, were the ones which students have found harder to pronounce.

It is possible to state that Pennington's hypothesis may be significant for the teaching of pronunciation through textual genres, since it encompasses those notions at different levels considering the socio-communicative function of the language. First grade students were allowed to write a text in order to support their speeches intelligibility once they were not considered proficient enough to participate in the debate. We believe the text might work as a scaffolding tool, making it possible for students to achieve a higher level of effectiveness in communication. Meanwhile, second graders were exposed to note-taking techniques, so that they were capable of creating their own topic list which they could refer to as source of arguments for their turns in the debate. Lastly, third grade students should perform in the debate in a more natural way, speaking without using any type of visual aid, including texts. The debate allowed for more interaction between the students and the teacher, so learners were not bored or discouraged to speak English. In addition, it fosters conversation, giving students the chance to learn to speak the English so that they can communicate effectively.

Due to the results of this research project, it's possible to enable other researchers to create new strategies of pronunciation teaching along with the use of diverse textual genres. Moreover, it was proven to be possible to insert the study of pronunciation aspects into regular education curricula.

\section{References}

BAKHTIN, M. Os gêneros do discurso. In: Estética da criação verbal. 4. ed. São Paulo: Martins Fontes, 2003. 
BAMBIRRA, M. R. A. A eficácia do uso de uma abordagem via gêneros textuais no ensino da habilidade de produção escrita em inglês como língua estrangeira, para alunos do Ensino Fundamental - um estudo de caso. Dissertação de Mestrado, Faculdade de Letras, Universidade Federal de Minas Gerais, 2004.

BAMBIRRA, M. R. A. Uma abordagem via gêneros textuais para o ensino da habilidade de leitura no Inglês Instrumental; The Especialist (PUC-SP), v. 28, p. 137-157, 2007.

BAUER, D. A.; ALVES, U. K. O ensino comunicativo de pronúncia nas aulas de inglês (L2) para aprendizes brasileiros: análise de um livro didático. Linguagem \& Ensino, Pelotas, v.14, n.2, p.287-314, jul./dez. 2011.

BRASIL. Orientações Curriculares para o Ensino Médio - Linguagens, Códigos e suas Tecnologias. v. 1. Brasília: MEC/SEB, 2006.

BROWN, H. D. Teaching by principles: an interactive approach to language pedagogy. Englewood Cliffs, NJ: Prentice Hall Regents, 1994.

CELCE-MURCIA, M.; BRITON, D. and GOODWIN, J. Teaching pronunciation: a reference for teachers of English to speakers of other languages. New York: Cambridge University Press, 2nd ed., 2010.

CHAPELLE, C. English language learning and technology. Amsterdam: John Benjamins, 2003.

COLLINS, B.; MEES, I. Practical phonetics and phonology: a resource book for students. Oxon: Routledge, 2008.

CRYSTAL, D. English as a global language. 2 nd ed. Cambridge: Cambridge University Press, 2003.

DIAS, R. A abordagem de ensino via gêneros textuais no livro didático de língua estrangeira: uma análise panorâmica. IN: SILVEIRA, E. M. (org.). As bordas da linguagem, Uberlândia: EDUFU, 2011. p. 259-282.

DOLZ, J.; SCHNEUWLY, B. Gêneros e progressão em expressão oral e escrita. Elementos para reflexões sobre uma experiência suíça (francófona). In: Gêneros Orais e escritos na escola. Campinas (SP): Mercado de Letras, 2004.

ELLIS, R. Instructed Second Language Acquisition: a Literature Review. Wellington, New Zealand: Ministry of Education, Research Division, 2005.

ELLIS, R. Second Language Acquisition. Oxford: Oxford, 1997.

JENKINS, J. The phonology of English as an international language. Oxford: Oxford University Press, 2000. 
LANTOLF, J., THORNE, S. L., POEHNER, M. (2015). Sociocultural Theory and Second Language Development. In B. van Patten \& J. Williams (Eds.), Theories in Second Language Acquisition (pp. 207226). New York: Routledge.

LIMA-JÚNIOR, R. M. Uma investigação sobre o efeito do ensino explícito da pronúncia na aula de inglês como língua estrangeira. Revista Brasileira de Linguística Aplicada, Belo Horizonte, v.10, n. 3, 2010. p. 747-771.

MEURER, J. L.; MOTTA-ROTH, D. (Orgs.) Gêneros Textuais: Subsídios para o ensino da linguagem. Bauru: EDUSC-Editora da Universidade do Sagrado Coração, 2002.

MINAS GERAIS. Proposta Curricular para Língua Estrangeira no Ensino Médio da Rede Estadual de Ensino de Minas Gerais. Belo Horizonte: SEE/MG, 2005.

MITCHELL, R.; MYLES, F. Second language learning theories. London: Arnold, 1998.

NETO, A. and VASCONCELLOS, M. Focus on Pronunciation: uma proposta para a abordagem de aspectos de pronúncia em língua estrangeira. Rev. de Letras, v. 1/2, n. 25, jan/dez. 2003. p.127-131.

PAIVA, V. Como se aprende uma língua estrangeira? In: ANASTÁCIO, E.B.A.; MALHEIROS, M.R.T.L.; FIGLIOLINI, M.C.R. (Orgs). Tendências contemporâneas em Letras. Campo Grande: Editora da UNIDERP, 2005.

PENNINGTON, M. C. Phonology in English language teaching. London: Longman, 1996.

PINTO, A. P. Gêneros Discursivos e Ensino de Língua Inglesa. In: DIONÍSIO, A. P.; MACHADO, A. R. e BEZERRA, M. A. (org.). Gêneros Textuais e Ensino. Rio de Janeiro: Editora Lucerna, 2002.

Raymond, E. Cognitive Characteristics. Learners with Mild Disabilities (pp. 169-201). Needham Heights, MA: Allyn \& Bacon, A Pearson Education Company, 2000.

RICHARDS, J. C.; RODGERS, T. S. Approaches and methods in language teaching. New York: Cambridge University Press, 2001.

SILVA, M. Estudo da interação em contexto de ensino de pronúncia da língua inglesa. Dissertação de Mestrado - Posling, Centro Federal de Educação Tecnológica de Minas Gerais (CEFET/MG), Belo Horizonte, 2012.

SWAIN, M.; KINNEAR, P.; STEINMAN, L. Sociocultural theory in second language education: an introduction through narratives. Bristol: Multilingual Matters, 2011. 
VYGOTSKY, L. S. Mind in Society: Development of Higher Psychological Processes, M. Cole, V. JohnSteiner, S. Scribner, \& E. Souberman (Eds.) Cambridge, MA: Harvard University Press, 1978.

Data de submissão: 21/09/2020 Data de aprovação: 23/10/2020.

\section{Anexo}

Questionário sobre aspectos relacionados ao conhecimento de pronúncia em língua inglesa.

1 Como você classificaria o seu nível de pronúncia em língua inglesa?
( ) bom
( ) regular
( ) ruim
( ) não sei dizer

2 Que palavras da língua inglesa você considera difíceis de se pronunciar?
( ) aquelas terminadas com 'th
( ) as homônimas (ex. bad-bed; eat-it)
( ) aquelas que possuem o as consoantes 'rl'seguidas
( ) aquelas com o som mudo da consoante (ex. listen; know)

3 Durante o período em que você teve aulas de inglês nas escolas anteriores à atual, a qual nível de pronúncia você acha que foi exposto?
( ) a um nível alto
( ) na mesma proporção de vocabulário e gramática
( ) a quase nada
( ) nunca aprendi pronúncia

4 Qual o seu conhecimento relacionado ao alfabeto fonético da língua inglesa?
( ) tenho conhecimento profundo
( ) conheço os símbolos fonéticos, mas não sei o que significam
( ) já ouvi falar
( ) não sei o que é 
5 Você saberia definir a diferença entre fluência, inteligibilidade e acuidade em relação à pronúncia da língua inglesa?
( ) $\operatorname{sim}$
( ) sim, mas não saberia reconhecê-los durante uma conversa.
( ) não
( ) não sei dizer

6 Por qual motivo você deixaria de falar inglês com alguém?
( ) por falta de vocabulário
( ) por medo de errar a pronúncia das palavras
( ) por dificuldades relacionadas à gramática
( ) não gosto de falar inglês

7 Qual a sua opinião a respeito da influência da pronúncia em uma conversa em inglês? Justifique.

( ) acho essencial...

( ) não converso muito em inglês ...

( ) não faz diferença ...

( ) não acho necessária... 